\title{
Media as the Battleground for Politics: The Relation Between Politicians and Media Barons in Indonesian Politics
}

\author{
Fahd Pahdepie ${ }^{1}$ \\ ${ }^{1}$ Postgraduate Student at School of International Relations, Monash University \\ Email: fahdisme@yahoo.com \\ Accepted Article: 29 Oktober 2014 \\ Published Article: 20 April 2015
}

\begin{abstract}
Media, especially television channels and newspapers have become another political battleground in Indonesian democracy. Some following scenes would describe how Indonesian media empires link to the political system. Media becomes the battleground for politics and there are two point-ofviews that could be taken. First, from the perspective of politicians, media is a medium to legitimate their political authority. Second, from the perspective of media barons, politics is an arena that can benefit their business empires. At this point, the marriage between political power and media ownership will eliminate the independence; consequently, the role of media in the concept of democracy to control the power will be diminished or even disappeared.
\end{abstract}

Keywords: Media, Political battleground, Political authority, Media barons

\section{A. INTRODUCTION}

Recently, Indonesia has just finished its biggest democracy event, the 2014 presidential election. The result favors Joko Widodo or Jokowi as the next Indonesian president for year 2014-2019, overcoming Prabowo Subianto as his only contestant. As the biggest Muslim populated democratic country, Indonesian politics is always fascinating. However, the most intriguing and important phenomenon in its last political event is the role of Indonesian media to intervene the election. During the campaign period, the term "media war" dominates academic debates in Indonesia regarding how media power tries to shape public preferences to vote particular candidate. The scene becomes more complicated after some Indonesian media barons, which most of them are affiliated to certain political parties, declare their standpoint to support the preferred candidate (Lim, 2014).

Thus, media especially television channels and newspapers have become another political battleground in Indonesian democracy. Some following scenes would describe how Indonesian media empires link to the political system. Owned by Aburizal Bakrie, Indonesian tycoon and the general leader of Golkar Party, Visi Media Asia or Viva Group including its national broadcasting channels TVOne and AnTV as well as their online news website Vivanews, clearly declare their support toward Prabowo Subianto. Other media baron named Harry Tanoesudibjo, the CEO of the MNC Group, which operates many national broadcasting channels such as RCTI TV, MNC TV, Global TV, and other TV-on-demand channels, takes the same side to his colleague bracing Prabowo Subianto in the race. On the opposite side, Surya Paloh, the leader of National Democratic Party (Nasdem), fully support Joko Widodo with his national 24-hours news channel MetroTV and his national newspaper Media Indonesia. By the same token, Dahlan Iskan, the 
minister for state-owned enterprises and owner of a nationwide stable of a local newspaper named JawaPos also secured the support of Jokowi (Bland, 2014).

Those stories are most likely bringing the conclusion that most Indonesian media are not independent. The media barons have used their media power to shape public preferences about the president candidates. From the political perspective, it seems that the media owners have tried to secure their political position for their own interests (Inglis, 2013, p. 15). Regarding that most media owners in Indonesia are also politicians or at least affiliated to certain political parties, this phenomenon could be seen as a marriage between media and political power (Prasetyawan, 2012), when the politicians and the media barons accumulate their powers to dominate the system.

This essay would try to examine the relationship between media ownership and its subjectivity in politics, in the sense of how the so-called media power or 'symbolic power' exercises its influence to intervene political circumstances. This paper would be divided into three parts. The first section will try to explain how media could be a battleground of politics. In this section, Indonesian case will be used to analyze how the phenomenon works; how the politics uses the media and vice versa. In the second part, this article will link the phenomenon to the theory of the paradox of media power. As a conclusion, in the third part, this piece will endeavor to answer the question of why does the concentration of the media ownership matter?

\section{B. METHODS}

This paper will analyze how the phenomenon works; and how the politics use the media and vice versa. In the second part, this article will link the phenomenon to the theory of the paradox of media power.

\section{RESULT AND DISCUSSION}

\section{Politics and the Need of Symbolic Power}

To answer the question why the term "media war" during the election in Indonesia related to the exercise of the so-called symbolic power within the political system, this essay would like to elaborate the term "power" in the context of politics. By understanding the concept of "power", the reason why the media could be a battlefield for political competition would most likely be clearer.

\section{Politics and Power}

In general sense, politics is the practice of influencing other people in global, civic or individual circumstances. The influence is needed to control others in pursuing individual welfare and security, then evolving to the larger and wider levels. In this notion, power is the essence of politics, as Morgenthau argued that politics is a struggle for power (Morgenthau, 1948).

According to Joseph S. Nye (2004), power is the ability to influence the behavior of others in order to get desired outcomes. However, Michel Barnett and Raymond Duvall (2005) believe that power is a multifaceted concept. They argue that there are two important dimensions which are needed to be considered in understanding power: first, the relation between the subjects, how they influence to each other; and, second, the particularity of its relations. Furthermore, they state that, 
Power is the production, in and through social relations, of effects on actors that shape their capacity to control their fate. This concept has two dimensions at its core: (1) the kinds of social relations through which actors' capacities are affected (and effected); and (2) the specificity of those social relations. Conventionally for social theorists, social relations can be viewed as being broadly of two kinds: relations of interaction among previously constituted social actors; or relations of constitution of actors as particular kinds of social beings. For the second dimension, the crucial distinction is whether the social relations of interaction or constitution through which power works are direct and specific, or indirect and socially diffuse. (Barnett \& Duvall, 2005, p. 45)

\section{Power Relation and Political Communication}

Power is being materialized and institutionalized through political systems including government. Borrowing Rousseau's theory, government's power comes from the so-called social contracts or social agreements between individuals within a society (Rousseau, 2012, p. 29). This contract creates specific relationship between people who govern (or rule) with other people who are being governed (or being ruled), this situation is what Robert A. Dahl called as "power as a relation among people" (Dahl, 1957, p. 202). Back to Barnett and Duvall statement, then, power is the production of effect within a group of people to control the system of the society (Barnett \& Duvall, 2005, p. 45).

In the logic of democracy, this "power relation" always needs to be regulated or limited. Dahl (1989) argued that to restrain this kind of relationship often needs "the standard by which one can judge the other" (Gastil, 2008, p. 8). Furthermore, he offers three ways to create the standard: (1) through political communication, (2) through political participation, and (3) through political recruitment. He believes that these political processes should be undertaken based on the principle of "deliberative ethics" or "deliberate engagement between the government and the public". Regarding this, John Gastil believes that the more often a system deliberates, the more readily it can meet the three criteria for the democratic political processes (Gastil, 2008, p. 8).

Nonetheless, this essay will focus only to elaborate the first criteria, the political communication. According to Norris (2004), this term is important to control the political power within a society for two reasons. First, it is important for the government to inform and educate the public. Second, it is important for the public to address their opinion to the government. Through the communication, both the government and the public can control each other to achieve a mutual relationship within the "social agreement". This communication also limits the power of both the government and the public within the political system. For example, when a government has programs, the programs should be well communicated to the public to make them successfully executed. However, by the same token, the public should also control how the government runs the programs. The public needs to keep track of those programs in terms of government's accountability, responsibility and transparency.

Political communication is an interactive process concerning the transmission of information among politicians, the news media and the public. The process operates down-wards from governing institutions towards citizens, horizontally in linkages among political actors, and also upwards from public opinion towards authorities. (Norris, 2004, p. 1)

In this light, as political communication is part of the so-called "power relation", the relationship between the government and the public is not always well-balanced reciprocal (Dahl, 1989). Dahl believes that in this kind of relationship, there will always be the more influential actor than others, 
and in terms of power relation, the government will tend to have a propensity to dominate its people (Dahl, 1957, p. 203). Even though there are many criticisms to Dahl regarding this idea, in terms of political relation, understanding the government as the more dominance agent compared to the public is still acceptable. Because, even in the most democratic country like the US, for instance, it is inevitable that the government still holds more power to rule its people in order to pursue common welfare and security than the other way around.

In this notion, government's propensity to control or to influence its people could be concluded as a form of "domination". It is because, in terms of power relation, to dominate is to have the capability to control and intervene other actors to do something that the actors would not otherwise do. In addition, according to Frank Lovett (2010), domination can only occur in a social relationship that involves two or more actors (individual or group). Lovett then defines domination in terms of social relation, dependence and arbitrary power as an imbalance, or sometimes injustice, relation. One actor is considered to dominate another actor when the second agent is in a dependent social relationship (2010, pp. 34-38). By and large, based on Lovett's definition about the term, the government is the more independent agent while the public is more dependent actor.

\section{Symbolic Power}

At this point, the discussion about symbolic power becomes relevant. The government, or the other actor who wants to dominate the public, for instance, a president candidate in the election, needs the so-called symbolic power to legitimate its authority in front of the public. The presence of authority is essential to claim the 'symbolic capital', because the authority related to status, honor, prestige, and recognition.

The idea of symbolic power is firstly coined by French sociologist Pierre Bourdieu (1930-2002) in his book titled La Distinction or Distinction(1984). Bourdieu argued that conventional powers such as economic, political and military are not more effective to influence people behavior compared to the 'symbolic' one. Furthermore, Bourdieu suggested that symbolic capitals, which could be referred as the values of individuals, including cultural roles, social hierarchy, historical background, honor, prestige or recognition, are more powerful than any other forms of capitals (money, land, machine of production). However, both symbolic capitals and economic capitals support each other. In this notion, the existence of the so-called symbolic capitals does not necessarily eliminate the role of other capitals, including economic capitals. They are coexistential. Even though, Bourdieu believed that symbolic capitals played the most significant role in his analysis of hierarchy of powers. At this point, said Bourdieu, only the ownership over the means of production alone (economic capitals) would not really dominant in a system, including political system, without its reliance to the symbolic capitals (Bordieu, 1984, p. 63).

Back to the discussion about the relationship between media and power, Bourdieu argued that media power is part of that symbolic power which define social reality(Bordieu, 1991). Through media, someone could legitimate its social status or images. For example, in most societies, those who appear in the media such as newspapers or television are usually important people-those who have different social class in the hierarchy of power. Besides that, media also have its ability to legitimate such power through the act of showing certain people who have lower social class or lesser power. For example, the news about terrorists or corruptors in the newspaper or news channel in television is the demonstration of, for instance, the government power over particular group of people. Consequently, the news is not only about actual events or information, but also the announcement of the existence of the powerful over the less powerful. John B. Thompson, elaborates this idea of the symbolic power in the media as "The capacity to intervene in the course 
of events, to influence the actions of others and indeed to create events, by means of the production and transmission of symbolic forms" (Thompson, 1995, p. 17).

\section{The Case of Indonesia}

In the case of Indonesian election that I provided at the beginning of this essay, Indonesian politicians have used the media to exercise their symbolic power. They want to legitimate their social status with preferred images through the media channels. The logic behind this is simple: if they could appear as good guys in the media, the public will like them, and then they will gather the votes in the election. It is in line to the statement of James W. Carey in his book titled Communication as Culture that, "...to contest media power is therefore to contest social reality" (Carey, 1989; Couldry \& Curran, 2003, p. 41).

Indonesian political situation sets a unique scene, as the most media barons in Indonesia are also politicians. By the same token, Indonesian public service media such as the Televisi Republik Indonesia (TVRI), the Radio Republik Indonesia (RRI), and the national news agency ANTARA, do not popular among Indonesian community due to their unattractive programs. In this situation, holding more than $70 \%$ of audience sharing in Indonesian, private media empires played significant role in shaping public opinions. For example, the MNC Groups, the media empire owned by Harry Tanoesudibjo, have a free-to-audience share of more than $25 \%$ only for their broadcasting channels. When Mr Tanoesudibjo supported Prabowo Subianto in the last Indonesian election, together with Aburizal Bakrie's TVOne and ANTV, they have more than $40 \%$ of free-to-air audience share (Bland, 2014). With such a big power like that, most politicians are most likely want to close to the media barons to shine their reputation. In the situation of election, the good news framing and their appearances in entertainment programs are important to lift up their electability. According to Chadwick (1989), with such situation, most politicians want to be the so-called "media-mates".

"The most dangerous community response to the concentration of media power is a sense of powerlessness. It is understandable because most coverage emphasizes the wealth and influence of 'barons'. Fawning or feckless politicians reinforce the impression" (Chadwick, 1989, p. 12)

However, different to Australian case, in Indonesia not only politicians that want to get closer to the media tycoons, but vice versa. Indonesian media barons also want to get closer to the political power to enlarge their business. By playing inside the political system, media owner could intervene the government regulations that could benefit their business. At this point, the discussion about media subjectivity and the matters of media independence become crucial (Inglis, 2013). According to Eko Maryadi, the chairman of the Independent Journalist's Alliance, during the 2014 presidential election, Indonesia has practiced bad example for other Southeast Asian countries in terms of media independence. He states that,

"Over the past five years, the Indonesian media has set a good example for media freedom in this region, with many countries such as Cambodia, Myanmar, Thailand and Timor Leste learning from us...Now we're falling into bad practices because of media owners interfering to blatantly promote their political interests." (Bland, 2014) 


\section{The Paradox of the Media Power}

Nick Chouldry and James Curran believe that media power is "an emergent form of social power" (Couldry \& Curran, 2003, p. 4). Media power has its own ability to flows the stream of information, knowledge, and images. Subsequently, media holds certain power to influence social structures, as well as intervene social conflicts (the word "conflict" here represents the dynamics of social interactions) (see Giddens, 1984). Through this kind of capability, in terms of media as the "emergent theme of social conflict", media has the power to circulate the symbolic power.

However, the adage of "the media are powerful" is more illusory than real. Even though media has its bargaining power against other sources of power, without the sources of information or the sources of "content" media is, in fact, powerless. Chouldry and Curran perceive this situation as "the paradox of the media power". They argue that it seems that media has its own power (to flow or to circulate the information), but in reality that such power is driven by other means of power, for example, the media owners or the government.

In this notion, the power of media is most likely just illusory (Couldry \& Curran, 2003, p. 1). It seems that media has the power to intervene or control the social conflicts, but in the reality media is only a "medium" that used by other sources of power such as political power (government) or economic power (businesses) to intermediate their interests. According to Chouldry and Curran,

One way of defining media power, if an unwieldy on, is a label of the net result of organizing a society's resource so that the media sector has significant independent bargaining power over and against other key sectors (big business, political elites, cultural elites, and so on). This seems straightforward until one realizes that the media's bargaining power (for example, over the framing of particular story) is of a curious sort: Media are unable to bargain over the basic rule of their existence, which is that they depend on "content" generated by others ...

Here we come to the heart of the apparent paradox about media power, which derives from the fact that such power faces two ways. From one direction (the more common direction of analysis) "media power" is a term we use to point to how other powerful forces use the intermediate mechanism of media (press report, television coverage, websites, and so on) to wage their battle (big business against labor, old-professional and class elites against new cultural elites, and so on). From this direction, media power disappears; it is merely the door through which the contestants for power pass en route the battle. (Couldry \& Curran, 2003, p. 3)

Back to the context of Indonesian politics, now it is understandable why Indonesian media barons need to affiliate with the political elites as well as engage in the political system. From the approach of "media-mates theory" as Paul Chadwick argues (1989), the politicians are placed as the agent that needs media publication to gain reputation, so the media barons are perceived to have more power than the political elites. On the contrary, from the perspective of "the paradox of the media power theory", the politicians (as one of the sources of power) have more control over the media, so the media owners need to have good relation with them to sustain their business empire.

At this point, the question why the media could be a battleground for politics becomes more relevant. Based on Indonesian example, both politicians and media barons have their own interests to each other. 


\section{CONCLUSION}

To sum up, based on the situation that well represented by Indonesian political context, it is clear that the concentration of media ownership really matters. The more the media ownership concentrate to one pole of power, the more powerful it can control the society. From the perspective of power distribution, the concentration of media ownership could be seen as the concentration of power itself. And any concentration of power could be a threat for democracy (see Inglis, 2013).

When the media becomes the battleground for politics, there are two point-of-views that could be taken. First, from the perspective of politicians, media is a medium to legitimate their political authority. Second, from the perspective of media barons, politics is an arena that can benefit their business empires. At this point, the marriage between political power and media ownership will eliminate the independence; consequently, the role of media in the concept of democracy to control the power will be diminished or even disappeared. In most non-democratic country, the state-owned media has lost its press independence (Inglis, 2013). If in democratic countries the media owners "sell" their media power to the politicians or to the state for the sake of bigger power, the public will suffer the loss. 


\section{References}

Barnett, M., \& Duvall, R. (2005). Power in International Politics. International Organization, 59 (1), 39-75.

Bland, B. (2014). Indonesia media barons line up for election fight. Asia Pacific. Retrieved September 3rd, 2014, from http://www.ft.com/cms/s/0/048a7812-ebca-11e3-8cef00144feabdc0.html - axzz3CDrdsZPK

Bordieu, P. (1984). Distinction. London, UK: Routledge.

Bordieu, P. (1991). Language and Symbolic Power. Cambridge, MA: Harvard University Press.

Carey, J. W. (1989). Communication as Culture. UK: Psychology Press.

Chadwick, P. (1989). Media Mates: Carving Up Australia's Media. South Melbourne: Macmillan.

Couldry, N., \& Curran, J. (2003). Contesting Media Power: Alternative Media in a Networked World. Lanham, Md: Rowman \& Littlefield

Dahl, R. A. (1957). The Concept of Power. Behavioral Science, 2(3), 201-2015.

Dahl, R. A. (1989). Democracy and its critics. New Haven, USA: Yale University Press.

Gastil, J. (2008). Political Communication and Deliberation. Thousand Oaks, CA: Sage Publishing.

Giddens, A. (1984). The constitution of society: Outline of the theory of structuration. Cambridge: Polity Pres.

Inglis, D. (2013). Theorising Media: Power, Form and Subjectivity. European Journal of Communication, 28(87), 87-89.

Lim, M. (Producer). (2014, September 3rd). Media in Indonesia's presidential election. [Audio Interview] Retrieved from http://theconversation.com/audio-qanda-media-in-Indonesiaspresidential-election-28902

Lovett, F. (2010). A General Theory of Domination and Justice. Oxford, UK: Oxford University Press.

Morgenthau, H. J. (1948). Politics Among Nations: The Struggle for Power and Peace. New York: Alfred A. Knopf.

Norris, P. (2004). Political Communication. 1-22. http://www.hks.harvard.edu/fs/pnorris/Acrobat/ PoliticalCommunicationsencyclopedia2.pdf

Nye, J. S. (2004). Soft Power: The Means to Success in World Politics. New York, USA: Public Affairs.

Prasetyawan, W. (2012). Image Construction in Poltitics: Political Advertisement in the 2009 Indonesian Election. Journal of Social Issues in Southeast Asia, 27(2012), 310-328. 
Rousseau, J.-J. (2012). Of The Social Contract and Other Political Writings. London, UK: Penguin Thompson, J. B. (1995). The Media and Modernity: A Social Theory of the Media. Canada: Stanford University Press. 
Media as the Battleground for Politics: The Relation Between Politicians and Media Barons in Indonesian Politics 